\title{
BIMBINGAN TEKNIS PENGELOLAAN KEUANGAN BADAN USAHA MILIK DESA
}

\author{
Naswar, Aminuddin, Syamsul Bachri, Muhammad Yunus \\ Wahid, Marthen Arie, Muhammad Zulfan Hakim \\ Dosen Fakultas Hukum Universitas Hasanuddin Makassar \\ email : naswar.bohari@ymail.com
}

\begin{abstract}
Congko Village is one of the villages in the district of Marioriwawo, Soppeng District. In terms of its formation, this village is a unit of government known as 'local self-government', the village formed or formed supra village government. BUMDes is obliged to make the financial statements of all BUM Desa business units every month honestly and transparently. In addition, BUMDes is also required to report the progress of BUM Desa business units to village communities through village meetings at least twice a year. BUMDes must perform systematically written records or bookkeeping of daily transactions. Listing recording generally uses an accounting system. The function of accounting is to present financial information to internal and external parties and as a basis for making decisions. BUMDes internal party is the manager and the Board of Commissioners, while the external parties are district governments, banks, and communities that provide equity, as well as tax officials.
\end{abstract}

Keywords: Financial Management, BUMDes.

\section{Abstrak}

Desa Congko adalah salah satu desa di distrik Marioriwawo, Distrik Soppeng. Dalam hal pembentukannya, desa ini adalah unit pemerintahan yang dikenal sebagai 'pemerintahan sendiri lokal', desa yang membentuk atau membentuk pemerintahan desa supra. BUMDes wajib membuat laporan keuangan semua unit usaha BUM Desa setiap bulan secara jujur dan transparan. Selain itu, BUMDes juga diharuskan melaporkan perkembangan unit bisnis BUM Desa kepada masyarakat desa melalui pertemuan desa setidaknya dua kali setahun. BUMDes harus melakukan catatan tertulis secara sistematis atau pembukuan transaksi harian. Pencatatan listing umumnya menggunakan sistem akuntansi. Fungsi akuntansi adalah untuk menyajikan informasi keuangan kepada pihak internal dan eksternal dan sebagai dasar untuk membuat keputusan. Pihak internal BUMDes adalah manajer dan Dewan Komisaris, sedangkan pihak eksternal adalah pemerintah kabupaten, bank, dan masyarakat yang menyediakan ekuitas, serta pejabat pajak.

Kata kunci: Manajemen Keuangan, BUMDes.

\section{PENDAHULUAN}

Desa Congko adalah salah satu desa yang berada di Kecamatan Marioriwawo, Kabupaten Soppeng. Dari segi pembentukannya, desa ini merupakan satuan pemerintahan yang dikenal dengan sebutan 'local self government', yakni desa bentukan atau dibentuk pemerintahan supradesa. Kekuatan utama dari desa semacam ini 
terletak pada kewenangannya untuk mengatur dan mengurus fungsi pemerintah berskala desa. Dahulu, di masa berlakunya UndangUndang Nomor 32 Tahun 2004, kewenangan yang dimaksud disebut sebagai kewenangan (sisa) yang tidak atau belum dilaksanakan oleh pemerintahan supradesa (kabupaten/kota).

Adanya perubahan sebutan 'kewenangan sisa' menjadi 'kewenangan berskala desa' dilatari oleh kenyataan tidak jelasnya fungsi pemerintahan seperti apa yang disebut dengan 'kewenangan sisa' itu akibat tidak adanya:regulasi (peraturan daerah) pemerintahan supradesa yang menetapkan fungsi pemerintahan dimaksud. Dengan perubahan sebutan tersebut, diharapkan adanya kejelasan mengenai fungsi pemerintahan berskala desa, sebab penetapannya tidak lagi digantungkan kepada regulasi pemerintahan supradesa, tetapi diatur secara mandiri oleh pemerintahan desa yang bersangkutan.

Pola penentuan fungsi pemerintahan desa yang demikian itu dikenal dengan ajaran rumah tangga formal, sebuah ajaran yang menghendaki keleluasaan bagi suatu entitas pemerintahan -in casu desa- guna mengatur dan mengurus sesuatu urusan pemerintahan seluas-luasnya. Desa begitu, desa dapat mengatur dan mengurus suatu urusan yang benar-benar signifikan guna kesejahteraan bersama, sepanjang urusan itu tidak atau belum menjadi urusan pemerintahan supradesa.

Namun demikian, bagi pemerintahan desa itu sendiri, pertanyaan yang belum mampu dijawab adalah, bagaimana menentukan 'kewenangan desa berskala lokal' itu, dan apa parameternya? Hal ini urgen diklarifikasi seperti yang disampaikan oleh Kepala Desa Congko, M. Jafar.

Namun, menurutnya, yang urgen untuk dipahami secara tepat oleh semua unsur stakeholders desa setempat adalah pengaturan mengenai hal-hal baru yang dimuat dalam UU No. 6 Tahun 2014 tentang Desa, di antaranya adalah pendapatan desa berupa 'dana desa' yang bersumber dari APBN. Pengaturan mengenai hal-hal baru tersebut, pada dasarnya memang memerlukan upaya pemasyarakatannya mengingat implementasinya sudah 'di depan mata'.

Wawancara dengan Kepala Desa Congko tersebut dilanjutkan dengan curah pendapat seputar penyelenggaraan pemerintahan desa setempat. Dari curah pendapat itu diidentifikasikan perlunya dilakukan sosialisasi terkait pengelolaan dana desa yang bersumber dari APBN khususnya peruntukan dana desa itu. Terkait hal ini, Kementerian Desa, Pembangunan Daerah Tertinggal, dan Transmigrasi telah menetapkan prioritas penggunaan dana desa Tahun 2015, di antaranya adalah pendirian dan pengembangan BUM Desa.

Langkah yang harus dilakukan oleh pemerintahan desa in casu 
Desa Congko adalah merumuskan kebijakan pendirian dan pengembangan BUM Desa dalam peraturan desa dan produk hukum desa lain (peraturan kepala desa). Untuk itu, pemerintahan desa yang bersangkutan dituntut untuk mampu mengenali kondisi dan potensi ekonominya guna merumuskan kebijakan yang terkait dengan pendirian dan pengembangan BUM Desa tersebut. Dengan begitu, pada tataran implementasinya kelak, kebijakan dimaksud dapat terlaksana secara efektif dan efektif dalam upaya meningkatkan taraf hidup dan kesejahteraan masyarakat desa yang bersangkutan. ${ }^{1}$

Titik krusialnya adalah, kebijakan pendirian dan pengembangan BUM Desa ini, bagi Desa Congko adalah suatu hal yang baru.Seperti dikatakan oleh Kepala Desa Congko, M. Jafar, hingga kini Desa Congko belum memiliki pengalaman mengenai seluk beluk manajemen keuangan desa.

Sebagai lembaga keuangan desa yang menjalankan bisnis keuangan (financial business) yang memenuhi kebutuhan usahausaha skala mikro yang dijalankan oleh pelaku usaha ekonomi Desa, BUMDes wajib untuk membuat laporan keuangan seluruh unit-unit usaha BUM Desa setiap bulan dengan jujur dan transparan.Selain itu, BUMDes juga wajib memberikan laporan perkembangan unit-unit usaha BUM Desa kepada masyarakat desa melalui musyawarah desa sekurang-kurangnya dua kali dalam satu tahun.

Secara umum, prinsip pembukuan keuangan BUMDes tidak berbeda dengan pembukuan keuangan lembaga lain pada umumnya. BUMDes harus melakukan pencatatan atau pembukuan yang ditulis secara sistematis dari transaksi yang terjadi setiap hari.Pencatatan transaksi itu umumnya menggunakan sistem akuntansi.Fungsi dari akuntansi adalah untuk menyajikan informasi keuangan kepada pihak internal dan eksternal dan sebagai dasar membuat keputusan.Pihak internal BUMDes adalah pengelola dan Dewan Komisaris, sedangkan pihak eksternal adalah pemerintah kabupaten, perbankan, dan masyarakat yang memberikan penyertaan modal, serta petugas pajak.

Dari kondisi yang dideskpripsikan di atas, jelas bahwa keberlakuan UU No. 6 Tahun 2014 dan peraturan pelaksanaannya, sepanjang menyangkut penggunaan dana desa khususnya di lingkungan pemerintahan Desa Congko tidak hanya dimaknai sebagai 'berkah' karena desa mendapatkan sumber penghasilan baru, tetapi juga menjadi tantangan (kalau tidak dikatakan 'masalah' baru) yang harus dapat diatasi oleh pemerintahan desa yang bersangkutan.

Tantangan yang dimaksud, yaitu pemahaman dan kemampuan menyusun manajemen keuangan BUM Desa.Menghadapi tantangan ini, pemerintahan Desa Congko perlu 'dikawal' untuk sesegera

${ }^{1}$ Nuhrawati, A. 2018. Hukum Dan Demokrasi Jalan Menuju Kesejahteraan Rakyat. Pleno Jure, 7(2), 16-27. 
mungkin meningkatkan kemampuan aparat desa untuk mengelola keuangan BUMDesa dengan baik dan benar.

\section{STATUS HUKUM KEUANGAN BUMDes}

BUMDes merupakan lembaga usaha yang didirikan berdasarkan peraturan desa (Perdes). Dari sisi pembentukannya itu, BUMDes terkategori sebagai badan hukum (rechtspersoon), yang bercirikan antara lain memiliki kekayaan sendiri yang terpisah dari kekayaan badan hukum desa yang membentuknya, dan dikelola sendiri oleh BUMDes bersangkutan, terpisah dari pengelolaan kekayaan desa. Namun demikian, meskipun pengelolaannya dipisahkan, terdapat hubungan antara kedua keuangan BUMDes dan keuangan desa tersebut. Hubungan ini dapat dilihat dari sisi permodalan BUMDes. Modal awal BUMDes bersumber dari APBDes. Modal awal ini berupa uang yang ditanamkan dalam BUMDes pada saat pendiriannya. Setelah BUMDes didirikan, desa dapat menanamkan lagi modalnya untuk menambah modal BUMDes. ${ }^{2}$

Kalau didekati dari perspektif teori badan hukum, sudah tentu, uang tadi yang dijadikan modal BUMDes baik dalam rangka pendirian maupun penambahan modal BUMDes, bukan lagi milik desa melainkan sudah berubah statusnya menjadi milik BUMDes. Akan tetapi, secara positiefrecht, UU No. 6 Tahun 2014 menentukan bahwa uang tersebut tetap merupakan uang milik desa, yang disebut dengan kekayaan desa yang dipisahkan. Ketentuan demikian ini sejalan dengan UU No. 17 Tahun 2003 dan PP No. 58 Tahun 2005 yang mengkualifikasikan kekayaan negara yang dipisahkan atau kekayaan daerah yang dipisahkan sebagai keuangan negara atau keuangan daerah. ${ }^{3}$

Status hukum keuangan BUMDes ini tidak tereduksi oleh adanya penyertaan modal masyarakat desa dalam BUMDes bersangkutan, yang berasal dari tabungan masyarakat atau simpanan masyarakat. Bahkan, dengan status hukum yang demikian, modal yang berasal dari masyarakat desa secara hukum (rechsbegrip) 'terhisap' menjadi keuangan desa.

\section{STRUKTUR MODAL BUMDes}

Modal BUMDes terdiri atas penyertaan modal desa dan penyertaan modal masyarakat. ${ }^{4}$ Penyertaan modal desa, seperti dikemukakan di muka, bersumber dari APBDes baik modal awal maupun modal tambahan BUMDes, disebut kekayaan desa yang dipisahkan. Selain itu, penyertaan modal desa dapat pula bersumber

2 Pasal 135 ayat (1) dan (3) PP No. 43 Tahun 2014 juncto Pasal 17 ayat (1) dan

(2) Permendesa, PDT, dan Transmigrasi No. 4 Tahun 2015.

${ }_{3}$ Moonti, R. M. 2018. Establishment Of Village Regulations In Realize Autonomy Village. Substantive Justice International Journal of Law, 1(2), 129-137.

4 lbid. 
dari luar APBDes. Sumbernya terdiri atas: ${ }^{5}$

a. hibah dari pihak swasta, lembaga sosial eknomi kemasyarakatan dan/atau lembaga donor yang disalurkan melalui mekanisme APBDes;

b. bantuan pemerintah pusat dan pemerintah daerah (provinsi, kabupaten/kota) yang disalurkan melalui mekanisme APBdes;

c. kerja sama usaha dari pihak swasta, lembaga sosial ekonomi kemasyarakatan dan/atau lembaga donor yang dipastikan sebagai kekayaan kolektif desa dan disalurkan melalui mekanisme APBDes;

c. aset desa yang diserahkan kepada APBDes sesuai dengan ketentuan peraturan peraturan perundang-undangan tentang aset desa.

Penting untuk dijelaskan, bahwa sumber-sumber yang disebut dalam poin a dan b dikualifikasi sebagai penyertaan modal desa, karena penyalurannya dilakukan melalui mekanisme APBDes. Ketika subjek di luar entitas desa menyisihkan sejumlah dana untuk BUMDes, pada saat dana itu dimasukkan ke APBDes sebelum disalurkan ke BUMDes, otomatis berubah status hukumnya menjadi dana APBdes, sehingga ketika disalurkan ke BUMDes, dana itu disebut modal desa yang disertakan dalam BUMDes.

Khusus poin c, aset desa yang dimaksud berupa barang berwujud yang bergerak maupun yang tidak bergerak $^{6}$ yang pengelolaannya tunduk pada rezim hukum yang tersendiri dan dibedakan dari pengelolaan uang. ${ }^{7}$ Hanya mengenai siklus tertentu saja, yaitu pengadaan aset, yang dikelola melalui mekanisme APBDes. Jika demikian, menjadi aneh jika penyaluran aset milik desa ke BUMDes harus dilakukan melalui mekanisme APBDes. Mestinya, penyaluran dilakukan melalui mekanisme tersendiri, yaitu melalui Perdes penyertaan modal berupa aset.

\section{PEMBUKUAN KEUANGAN BUMDes}

BUMDes harus melakukan pencatatan atau pembukuan yang ditulis secara sistematis dari transaksi yang terjadi setiap hari. Pencatatan transaksi itu umumnya menggunakan sistem akuntansi. Fungsi dari akuntansi adalah untuk menyajikan informasi keuangan kepada pihak internal dan eksternal dan sebagai dasar membuat keputusan. ${ }^{8}$ Pihak internal BUMDes adalah pelaksana operasional dan pengawas, sedangkan pihak eksternal adalah pemerintah desa

5 Pasal 135 ayat (4) dan (5) PP N0. 43 Tahun 2014 juncto Pasal 18 ayat (1) Permendesa, PDT, dan Transmigrasi No. 4 Tahun 2005

6 Pasal 76 UU No. 6 Tahun 2014.

7 Kadir, Y., \& Moonti, R. M. 2018. Pencegahan Korupsi Dalam Pengelolaan Dana Desa. Jurnal IUS Kajian Hukum dan Keadilan, 6(3), 430-442.

8 Bunga, M., Aswari, A., \& Djanggih, H. 2018. Konsepsi Penyelamatan Dana Desa Dari Perbuatan Korupsi. Halu Oleo Law Review, 2(2), 448-459. 
dan masyarakat yang memberikan penyertaan modal, dan petugas pajak. Secara umum tujuan dilakukannya pembukuan adalah:

1. Untuk mengetahui perkembangan BUMDes dari waktu ke waktu, baik perkembangan omzet penjualan, laba/rugi maupun struktur permodalan.

2. Untuk mengetahui kemungkinan kerugian sejak dini, sehingga gulung tikar bisa dihindari.

3. Untuk mengetahui kondisi persediaan barang/jasa setiap saat, sehingga dapat digunakan untuk menyusun strategi manajemen persediaan. Pada unit usaha dagang yang disebut persediaan adalah barang dagangan. Pada unit usaha penyewaan adalah barang sewaan, sedangkan pada unit simpan pinjam adalah persediaan uang.

4. Untuk mengetahui sumber dan penggunaan dana BUMDes, sehingga bisa mengevaluasi kinerja keuangan BUMDes seperti likuiditas, solvabilitas maupun rentabilitas perusahaan.

\section{a. Pengertian Harta}

Harta dalam pengertian akuntansi adalah semua barang dan hak milik BUMDes dan sumber ekonomi lainnya. Harta BUMDes dapat dibedakan menjadi tiga, yaitu harta lancar, harta tetap, dan harta tidak berwujud.

Harta lancar atau umumnya disebut aktiva lancar adalah uang kas/bank atau harta lain yang dapat segera dicairkan menjadi kas. Harta yang termasuk dalam kelompok ini adalah:

1. Kas

Mata uang rupiah dan surat-surat berharga yang dimiliki oleh BUMDes.

\section{Piutang dagang}

Tagihan sejumlah uang kepada pihak lain (konsumen) dari suatu transaksi yang akan dibayar pada tanggal jatuh tempo sesuai dengan ketentuan yang disepakati bersama. Misalnya, unit usaha BUMDes menjual beras kepada konsumen yang sisa pembayarannya akan dibayar lunas pada dua bulan mendatang.

3. Penghasilan yang akan diterima

Adalah pendapatan yang berupa uang yang akan diterima pada masa tertentu dari hasil suatu usaha. Misalnya, unit usaha BUMDes menerima pesanan barang dari pemerintah kabupaten yang akan dibayar lunas setelah barang itu dikirim semua dan dinyatakan benar sesuai dengan perjanjian. Dalam transaksi ini BUMDes belum menerima sama sekali pembayaran. Namun sudah terjadi persetujuan untuk membayar dari pihak pembeli dalam kurun waktu yang disepakati bersama. 
4. Biaya yang dibayar di muka

Adalah pemberian uang muka kepada penjual atas barang-barang yang dibeli BUMDes. Misalnya, unit usaha BUMDes memesan sejumlah barang dagangan dan memberikan uang muka sebesar $40 \%$ dari keseluruhan harga yang harus dibayar.

\section{Persediaan}

Adalah semua persediaan barang dagangan yang dijual untuk menghasilkan keuntungan.

\section{Perlengkapan}

Adalah semua kebutuhan untuk menunjang kelancaran operasi BUMDes, seperti alat tulis kantor (ATK) dan perlengkapan lainnya.

Harta tetap umumnya disebut sebagai aktiva tetap adalah semua harta yang dimiliki BUMDes untuk menjalankan usahanya. Misalnya, BUMDes membeli tanah dan membangun gedung untuk memulai usahanya. Membeli mesin penggilingan padi dan kendaraan angkutan dan timbangan serta alat-alat pendukung. Maka tanah, gedung, mesin, kendaraan, dan peralatan adalah dinamakan aktiva tetap. Untuk barang-barang yang mengalami keausan biasanya dibuat biaya penyusutan. Tujuannya agar untuk memperoleh barang pengganti yang baru, BUMDes sudah memiliki cukup dana. Besarnya biaya penyusutan ditetapkan berdasarkan perkiraan usia peralatan yang dimiliki (5-10 tahun) dan perkiraan atau estimasi tingkat kenaikan harga pada masa mendatang.

Harta tidak berwujud adalah harta yang dimiliki BUMDes, tetapi tidak tampak. Harta ini merupakan hak istimewa atau sesuatu yang menguntungkan dari bisinis yang dijalankan. Misanyan, BUMDes mampun menghasilkan jenis makanan sehat yang tahan lama untuk semua usia. Maka produk itu dimintakan hak paten agar memperoleh perlindungan dari pemerintah, sehingga perusahaan lain tidak diizinkan untuk menghasilkan produk yang sama apalagi memalsukan produk tersebut.

\section{b. Hutang}

Dalam menjalankan usaha seringkali terjadi hutang piutang dan peristiwa itu dipandang wajar dalam aktivitas bisnis. Hutang merupakan kewajiban yang harus dibayar pada masa mendatang (sesuai dengan kesepakatan yang dibuat) akibat dari suatu transaksi. Berdasarkan waktu pembayaran, hutang dapat dibedakan menjadi dua, yaitu hutang jangka pendek dan hutang jangka panjang.

Hutang jangka pendek adalah semua kewajiban yang harus dibayar/dilunasi dalam waktu kurang dari satu tahun. Terdapat tiga jenis hutang jangka pendek, yaitu:

\section{Hutang dagang}

Adalah semua kewajiban yang harus diselesaikan dalam waktu maksimum satu tahun. Misalnya, BUMDes memiliki unit usaha 
industri makanan yang kebutuhan bahannya dipasok oleh perusahaan lain. Pembelian bahan baku industri makanan tersebut akan dibayar dalam jangka waktu tiga bulan. Maka BUMDes memiliki hutang dagang kepada perusahaan pemasok bahan baku industri makanan.

2. Biaya yang akan dibayar

Adalah hutang yang terjadi akibat biaya sewq barang atau kendaraan atau peralatan untuk keperluan usaha. Misalnya, BUMDes menyewa truk untuk mengangkut produk-produk hasil pertanian. Pembayarannya akan diselesaikan jika semua barang sudah terangkut dan masuk di gudang. Maka biaya sewa truk yang belum dibayar merupakan biaya hutang.

\section{Penghasilan yang diterima di muka}

Adalah penerimaan pembayaran dari usaha yang dijalankan, namun kewajiban yang harus dipenuhi belum selesai. Misalnya, BUMDes menerima pesanan makanan dari pemerintah kabupaten untuk perayaan haru kemerdekaan nasional. Pemerintah kabupaten membayar sebagian dari keseluruhan harga makanan yang dipesan (uang muka/down payment). Maka penerimaan pembayaran dimuka ini merupakan hutang, karena kewajibannya belum diselesaikan.

Hutang jangka panjang adalah semua kewajiban yang harus diselesaikan dalam waktu lebih dari satu tahun. Jika penyerta modal dalam BUMDes diperlakukan sebagai penabung dan berjangka waktu misalnya tiga tahun untuk dapat mengambil kembali tabungannya (depposito). Maka modal yang diterima dari masyarakat merupakan hutang jangka panjang. Namun, jika penyerta modal diperlakukan sebagai bagian pemilik usaha yang berhak memperoleh bagian keuntungan (deviden). Maka modal masyarakat itu tidak termasuk hutang. Dalam kasus yang kedua, modal itu menjadi harta BUMDes.

\section{c. Biaya dan Pendapatan}

Salah satu prinsip dasar akuntansi adalah mengetahui kondisi keuangan BUMDes. Kondisi keuangan perusahaan dapat diketahui dari perbandingan besarnya pendapatan yang diterima dan biayabiaya yang harus dikeluarkan.

Pendapatan (income) adalah harta/aktiva perusahaan sebagai akibat terjadinya transaksi yang mengutungkan. Misalnya, BUMDes membeli produk hasil pertanian per kg Rp. 2.500,- dan dijual di pasar dengan harga per kg Rp. 3.000,- Maka selisih antara harga beli dengan harga jual sebesar Rp. 500,- merupakan pendapatan BUMDes.

Biaya (cost) adalah harta yang digunakan untuk menghasilkan pendapatan dalam satu periode tertentu yang habis terpakai. Terdapat tiga jenis biaya yang umumnya harus dibayar oleh 
perusahaan, yaitu:

a. Harga pokok penjualan, yaitu semua biaya yang harus dikeluarkan secara langsung atau tidak langsung untuk menghasilkan produk (barang atau jasa) yang akan dijual. Misalnya, BUMDes memiliki unit usaha produksi makanan yang dijual kepada supermarket. Maka semua bahan baku dan upah karyawan merupakan harga pokok penjualan.

b. Biaya operasi, yaitu seluruh pengeluaran perusahan yang digunakan untuk menjalankan usaha. Biaya operasi umumnya dibedakan menjadi dua, yaitu (1) biaya penjualan -merupakan biaya yang dikeluarkan berkenaan dengan aktivitas penjualan produk (barang atau jasa); (2) biaya umum dan administrasi merupakan biaya yang dikeluarkan untuk menunjang aktivitas penjualan produk seperti, alat tulis kantor, telepon, listrik, air, dan gaji perusahaan kantor. Misalnya, BUMDes menjual produknya menggunakan jasa perantara (salesman). Maka biaya yang dikeluarkan untuk memberi imbalan (fee) kepada perantara dinamakan biaya operasi.

c. Biaya lain-lain, yaitu biaya-biaya yang tidak termasuk di dalam harga pokok penjualan dan biaya operasi. Misalnya, BUMDes memiliki pinjaman pada sebuah bank dan membayar bunga pinjaman. Maka bunga pinjaman merupakan biaya lain-lain.

\section{d. Bukti-bukti}

Dalam akuntansi dikenal sifat-sifat bukti yang harus ada di dalamnya. Tanpa adanya sifat bukti-bukti tersebut, maka pencatatan atau pembukuan menjadi tidak memiliki makna. Sifat bukti-bukti tersebut berkaitan:

a. Sifat transaksi

Ini menunjuk pada jenis transaksi yang dibuktikan dalam catatan. Misalnya, pembayaran hutang, pembelian bahan baku, pembayaran sewa, penerimaan hasil penjualan produk (barang atau jasa), dan lain-lain.

b. Menyebutkan pihak-pihak yang terlibat

Dalam proses transaksi umumnya terdapat dua atau lebih pihakpihak yang terlibat. Siapa saja yang terlibat dalam prose situ harus dijelaskan untuk selanjutnya dicatat dalam buku jurnal. Misalnya, BUMDes melakukan pembelian bahan baku dari UD Makmur tunai senilai Rp. 2.500.000,-. Dalam kasus ini pihak UD Makmur sebagai penjual dan BUMDes sebagai pembeli.

c. Menyebutkan jenis barang atau jasa dalam transaksi

Jenis barang atau jasa yang dibeli atau dijual harus dilakukan pencatatan secara benar. Misalnya, dari kasus di atas BUMDes membeli bahan baku berupa tepung gandum sebanyak $5 \mathrm{kwt}$.

d. Menyebutkan tanggal transaksi 
Tanggal transaksi harus dibuat supaya diketahui kapan peristiwa itu terjadi dan berapa banyak dana yang diterima atau dikeluarkan. Misalnya, dari kasus di atas BUMDes membeli bahan baku berupa tepung gandum dari UD Makmur pada tanggal 16 April 2016.

Beberapa contoh bukti transaksi yang diperlukan dalam pencatatan/pembukuan menggunakan akuntansi, yaitu:

a. kuitansi, yaitu surat tanda bukti pembayaran sejumlah uang yang dibuat oleh pihak penerima uang dari suatu transaksi.

b. nota, yaitu tanda bukti pembelian yang diberikan oleh penjual, biasanya dibuat rangkap dua. Rangkap pertama diberikan kepada pembeli, sedangkan rangkap yang kedua disimpan oleh penjual.

c. cek, yaitu surat perintah kepada bank untuk memberikan sejumlah uang sebagaimana yang termuat di dalam cek.

d. bon, yaitu tanda bukti pembelian yang dibuat oleh penjual. Perbedaannya dengan nota adalah bon umumnya tidak dibuat rangkap dua, tetapi hanya satu lembar.

e. faktur, yaitu bukti perhitungan penjualan barang atau jasa yang pembayarannya dilakukan kemudian atau tidak dengan cara tunai. Pembuatan faktur biasanya dilakukan rangkap tiga, masing-masing memiliki warna yang berbeda-beda. Salinan pertama diberikan kepada pembeli, salinan kedua disimpan penjual setelah ditandatangani pembeli dan salinan ketiga disimpan di dalam buku faktur. Umumnya faktur mencantumkan alamat pembeli secara rinci, seperti nama jalan, nomor, dan nomor telepon.

\section{e. Proses Melakukan Pembukuan}

Bagi perusahaan pemula, pembukuan dapat dilakukan secara sederhana, yaitu: ${ }^{9}$

a. Membuat dan mengumpulkan bukti transaksi, seperti kuitansi, nota/bon pembelian/penjualan, dan sebagainya.

b. menyusun buku kas harian/arus kas/cah flow. Apabila BUMDes mengalami perkembangan sehingga transaksinya bertambah banyak setiap harinya, maka pembukuannya dapat ditambah dengan:

1. Membuat daftar nomor rekening, tujuannya adalah untuk memudahkan bagi pelaksana operasioanal BUMDes mengetahui besarnya penerimaan dan pengeluaran dari setiap kelompok (harta, hutang, modal, pendapatan, biaya).

2. Membuat buku besar atau disebut juga buku pembantu. Buku ini dapat memberikan informasi tentang kondisi rekening pada setiap saat dibutuhkan.

Apabila BUMDes sudah berkembang, maka pembukuannya ditambah dengan:

9 Pusat Kajian Dinamika Sistem Pembangunan Fakultas 
1. Membuat neraca saldo -data keuangan pada neraca saldo diambil dari buku besar. Saldo setiap rekening dapat dihitung dengan cara menambah/mengurangi persediaan awal dengan mutasi selama periode pembukuan. Hasilnya dikurangi dengan persediaan akhir.

2. Membuat laporan keuangan -data laporan keuangan ini diambilkan dari neraca saldo. Laporan keuangan diperlukan untuk mengetahui kinerja keuangan BUMDes secara keseluruhan, selama satu periode (biasanya satu tahun). Laporan keuangan ini terdiri dari neraca, laporan rugi/laba dan laporan perubahan modal.

\section{PERTANGGUNGJAWABAN}

Pelaksana operasional BUMDes bertanggung jawab kepada penasihat yang secara ex ofiicio dijabat oleh kepala desa. Laporan pertanggungjawaban BUMDes disampaikan pada setiap akhir periode, melalui forum rembug desa (musyawarah desa). Mekanisme dan tata tertib pertanggungjawaban ini disesuaikan dengan AD dan ART BUMDes bersangkutan.

Isi laporan pertanggungjawaban meliputi: ${ }^{10}$

1. Laporan kinerja pelaksana operasional selama satiu periode.

2. Laporan usaha yang menyangkut realisasi kegiatan usaha, upaya pengembangan, indikator keberhasilan, dan sebagainya.

3. Laporan keuangan termasuk rencana pembagian hasil usaha.

4. Rencana-rencana pengembangan usaha yang belum terealisasi.

\section{SIMPULAN}

BUMDes merupakan lembaga usaha yang didirikan berdasarkan peraturan desa (Perdes). BUMDes memiliki kekayaan sendiri yang terpisah dari kekayaan badan hukum desa yang membentuknya dan dikelola sendiri oleh BUMDes bersangkutan, terpisah dari pengelolaan kekayaan desa. Meskipun pengelolaannya dipisahkan, terdapat hubungan antara kedua keuangan BUMDes dan keuangan desa tersebut. Hubungan ini dapat dilihat dari sisi permodalan BUMDes dimana Modal awal BUMDes bersumber dari APBDes.

\section{DAFTAR PUSTAKA}

Anonim, Buku Panduan Pendirian dan Pengelolaan Badan Usaha Milik Desa, kerjasama Departemen Pendidikan Nasional dengan Pusat

10 Zulkarnain Ridlwan, 'Urgensi Badan Usaha Milik Desa (BUMDes) dalam Pembangunan Perekonomian Desa', Jurnal Fiat Justitia, Fakultas Hukum Universitas Lampung, Bandar Lampung, Volume 8 Nomor 3, Juli-September 2014, hlm. 437-438. 
Kajian Dinamika sistem Pembangunan (PKDSP) Fakultas Ekonomi Universitas Brawijaya, Malang, 2007.

Anom Surya Putra, Badan Usah Milik Desa: Spirit Usaha Kolektif Desa, Kementerian Desa, PDT, dan Transmigrasi RI, Jakarta, 2015.

Bunga, M., Aswari, A., \& Djanggih, H. 2018. Konsepsi Penyelamatan Dana Desa Dari Perbuatan Korupsi. Halu Oleo Law Review, 2(2), 448459.

Nuhrawati, A. 2018. Hukum Dan Demokrasi Jalan Menuju Kesejahteraan Rakyat. Pleno Jure, 7(2), 16-27.

Moonti, R. M. 2018. Establishment Of Village Regulations In Realize Autonomy Village. Substantive Justice International Journal of Law, 1(2), 129-137.

Kadir, Y., \& Moonti, R. M. 2018. Pencegahan Korupsi Dalam Pengelolaan Dana Desa. Jurnal IUS Kajian Hukum dan Keadilan, 6(3), 430-442.

Undang-Undang Nomor 6 Tahun 2014 tentang Desa.

Peraturan Pemerintah Nomor 43 Tahun 2014 tentang Peraturan Pelaksanaan Undang-Undang Nomor 6 Tahun 2014 tentang Desa.

Peraturan Menteri Desa, Pembangunan Daerah Tertinggal, dan Transmigrasi Nomor 2 Tahun 2015 tentang Pedoman Tata Tertib dan Mekanisme Pengambilan Keputusan Musyawarah Desa.

Peraturan Menteri Desa, Pembangunan Daerah Tertinggal, dan Transmigrasi Nomor 4 Tahun 2015 tentang Pendirian, Pengurusan dan Pengelolaan, dan Pembubaran Badan Usaha Milik Desa.

Peraturan Manteri Desa, Pembangunan Daerah Tertinggal, dan Transmigrasi No. 5 Tahun 2015 tentang Penetapan Prioritas Penggunaan Dana Desa Tahun 2015. 